\title{
Germas Covid-19 Bersama Ibu-Ibu Warga Dusun Ireng Lauk Desa Jatisela
}

\author{
Nofisulastri1, Nurdin2 \\ ${ }^{1}$ Dosen Pendidikan Biologi, FSTT Undikma \\ ${ }^{2}$ Dosen Pendidikan Olahraga dan Rekreasi, FIKKM Undikma \\ E-mail korespondensi : nofisulastri@ikipmataram.ac.id
}

\begin{abstract}
Abstrak. Wabah virus Covid-19 telah menjadi pandemic dunia dan memasuki Indonesia sekitar awal tahun 2020. Langkah-langkah penanggulangan terpadu termasuk keterlibatan seluruh komponen masyarakat perlu dilakukan dengan menggali potensi yang dimiliki masyarakat agar berdaya dan mampu berperan serta mencegah penularan Covid-19. Bentuk Pendekatan kesehatan masyarakat yang dapat dilakukan berupa kegiatan GERMAS melalui pendekatam keluarga. Kegiatan pengabdian ini merupakan bentuk sinergitas kegiatan KAGAMA NTB dengan melibatkan dosen Undikma untuk memberikan sosialisasi terkait Covid-19 dan GERMAS mencuci tangan dan hidup sehat. Tahapan kegiatan pengabdian masyarakat ini dilaksanakan tertanggal 11 sampai dengan 25 April 2020 meliputi communication, design, execution, dan disseminate. Sasaran kegiatan adalah ibu-ibu PKK perwakilan dusun Ireng Lauk sebanyak 10-15 orang. Kegiatan pengabdian dilaksanakan beberapa sesi yaitu sesi sosialisasi materi, sesi pelatihan GERMAS (gerakan mencuci tangan sehat dan senam imun), sesi tanya jawab dan quiz berhadiah, dan diakhiri penutupan berupa senam bersama dan pembagian souvenir. Kegiatan berlangsung cukup lancar dengan antusiasme peserta yang melebihi permintaan dan kegiatan berlangsung waktu yang cukup panjang pada sesi tanya jawab.
\end{abstract}

Kata Kunci : Germas, Covid-19, Ireng Lauk

\section{PENDAHULUAN}

Covid-19 dinyatakan sebagai pandemi dunia oleh WHO dan ditetapkan Pemerintah sebagai bencana non alam berupa wabah penyakit yang perlu dilakukan langkah-langkah penanggulangan terpadu termasuk keterlibatan seluruh komponen masyarakat (Kemenkes, 2020). Maka, pemberdayaan masyarakat dalam pencegahan COVID-19 adalah segala upaya yang dilakukan oleh seluruh komponen masyarakat dengan menggali potensi yang dimiliki masyarakat agar berdaya dan mampu berperan serta mencegah penularan Covid-19.

Pendekatan kesehatan masyarakat yang diluncurkan Kementrian Kesehatan pada tahun 2016 adalah pendekatan keluarga dengan 12 indikator keluarga sehat dan Gerakan Masyarakat Hidup Sehat (GERMAS) yang berfokus pada 3 aspek perubahan perilaku yaitu melakukan aktivitas fisik, mengonsumsi sayur dan buah, dan melakukan pemeriksaan kesehatan secara berkala untuk mendeteksi faktor resiko yang ada pada setiap orang (Junita dkk., 2020). Namun terkait permasalahan wabah Covid-19, perlu dilakukan pembahasan kembali. Pendekatan kesehatan masyarakat yang diluncurkan Kementrian Kesehatan pada tahun 2020 adalah pendekatan keluarga berupa pendampingan dengan tahapan berbentuk pendataan kesehatan warga di RT/RW/Desa, mempelajari Pendekatan kesehatan, mempelajari faktor penyebab penularan Covid19 dan potensi wilayah, musyawarah masyarakat RT/RW/Desa, penyusunan rencana kegiatan, pelaksanaan teknis kegiatan dan keberlangsungan kegiatan.

Kegiatan pengabdian ini merupakan bentuk sinergitas kegiatan KAGAMA NTB dengan melibatkan dosen Undikma untuk memberikan sosialisasi Covid-19 dan GERMAS pencegahan penularannya dengan wilayah sasaran adalah lingkungan sekitar tim pengabdi. Kegiatan pengabdian ini diawali dilakukan sosialisasi di Desa Jatisela Kecamatan Gunungsari. Berdasarkan data Balai Pusat Statistik wilayah Lombok Barat (2019) 
menegaskan bahwa luas wilayah desa jatisela sebesar $2.61 \mathrm{Km}^{2}$ dengan rincian jumlah penduduk 8343jiwa, 6 dusun, doiminasi pekerjaan petani dan buruh bangunan, fasilitas kesehatan (poskesdes dan dokter praktek) sebanyak 2 dan tenaga medis sebanyak 5 orang.

Menimbang keterbatasan tenaga medis untuk melibatkan kegiatan sosialisasi Covid-19 dan perlunya strategi yang cepat menimbang permasalahan penyebaran wabah mulai memasuki NTB. Maka, oleh tim pengabdi memilih wilayah terdekat dan dirasakan perlu adanya pemberian informasi. Berdasarkan diskusi dan persetujuan perwakilan aparat dusun wilayah desa Jatisela dan mempertimbangkan kondisi lingkungan pemukiman yang berkategori belum memenuhi persyaratan pemukiman sehat, dan didukung yang jumlah penduduknya notabene berpendidikan rendah, maka kegiatan ini dilaksanakan dijadwalkan diawal di dusun Ireng Lauk.

\section{METODE PELAKSANAAN KEGIATAN}

Seluruh tahapan kegiatan pengabdian masyarakat ini dilaksanakan selama 2 (dua) minggu sejak tertanggal 11 sampai dengan 25 April 2020 meliputi communication, design, execution, dan disseminate. Sasaran kegiatan adalah ibu-ibu PKK perwakilan dusun Ireng Lauk sebanyak 10-15 orang dengan titik lokasi utama kegiatan di rumah Ketua RT 03.

Gambaran umum metode pelaksanaan merupakan pengembangan Fauzie dkk (2018) dan pertimbangan situasi sesuai kebutuhan, yaitu:

(1) Komunikasi (Communication) meliputi pembicaraan dengan mitra terkait dengan hakikat pengabdian masyarakat sebagai bagian dari pelaksanaan Tri Darma Perguruan Tinggi. Dalam pada ini disampaikan tentang tujuan dan rencana pengabdian masyarakat, dan penegasan bahwa kegiatan dilakukan oleh dosen-dosen yang kapabel dengan materi terkait. Tahap ini dilalui dengan tahap survei dan observasi dengan keluaran berupa surat kesediaan mitra untuk menerima kegiatan pengabdian masyarakat;

(2) Perancangan (Design) meliputi :

a. observasi dan legalisasi meliputi pendataan tentang kondisi mitra, mengidentifikasi permasalahan mitra, merumuskan solusi dan penjadwalan kegiatan;

b. Strategi, menunjuk pada penyusunan materi sosialisasi dan teknik penyampaian, pembagian tugas, dan finalisasi jadwal kegiatan;

(3) Eksekusi, menunjuk pada pelaksanaan puncak kegiatan bersama target sasaran berisikan sosialisasi pengenalan virus Covid-19, gejala klinis penularan virus Covid-19, dan langkah GERMAS merunut Panduan Kemkes RI (2020) dan Anugerah dkk (2019)

(4) Disseminate, berupa penyebaran dan penempelan famplet di beberapa titik lokasi dusun Ireng Daye sebagai upaya informasi GERMAS melawan Covid-19

\section{HASIL KEGIATAN YANG DICAPAI}

Prosesi pelaksanaan program kegiatan pengabdian ini diawali tertanggal 11 April 2020 dengan koordinasi perwakilan Kagama NTB bersama dosen Undikma yang memungkinkan berkapabel mendukung keberhasilan kegiatan. Setelah melalui penunjukkan dan penugasan tim, maka tim pengabdi bersama salahsatu warga Dusun Ireng Lauk (ibu Sutiani) melakukan pembicaran dalam pembagian tugas selanjutnya. Selanjutnya, tim pengabdi melaksanakan tahap survei dan observasi (estimasi kegiatan selama 2 hari) dengan keluaran berupa surat kesediaan mitra (pengurus Ibu PKK dan Ketua RT) untuk menerima kegiatan pengabdian masyarakat nantinya. Legalisasi surat kemitraan atau kesediaan pelaksanaan kegiatan difasilitasi oleh ibu Sutiani sedangkan tim pengabdi bertugas melakukan wawancara pada calon sasaran target sebagai bentuk pengidentifikasiaan permasalahan mitra dan penjelasan gambaran kegiatan yang akan dilaksanakan. Bersama Ketua RT 03 sebagai tuan rumah kegiatan dan 
perwakilan pengurus ibu PKK (2 orang) memfinalisasi penjadwalan kegiatan sosialisasi yaitu tertanggal 23-24 April 2020.

Pelaksanaan puncak kegiatan bersama target sasaran dilaksanakan tertanggal 24 April 2020 dari pukul 19.00 - 20.00 Wita. Kegiatan akhirnya dilaksanakan di malam hari dimana direncanakan sebelumnya di sore hari dikarenakan faktor cuaca sehingga oleh pihak target sasaran meminta diundur. Kegiatan sosialisasi dilakukan prosesi teknis GERMAS Covid-19 yaitu setiap peserta (sasaran) terlebih dahulu menggunakan hansanitizer dan pengaturan jarak duduk antar peserta kegiatan. Namun seiring berjalan kegiatan jumlah peserta yang semula diprediksi hanya maksimal 10 orang menjadi 17 orang ditambah 6 orang (pengurus RT dan pemuda setempat), sehingga social distancing tidak bisa memenuhi prasyarat dengan keterbatasan luas lokasi kegiatan.

$$
\text { Kegiatan sosialisasi GERMAS }
$$
dilaksanakan dalam beberapa sesi yaitu sesi pemberian materi, sesi pelatihan GERMAS, sesi tanya jawab dan quiz, dan diakhiri penutupan. Sesi pertama meliputi pemberian pamphlet, pengenalan tim dan penjelasan teknis tujuan kegiatan pengabdian oleh bapak Nurdin M.Pd., durasi estimasi 5-7 menit. Selanjutnya, pemberian materi terkait pengenalan dan gejala klinis penularan virus Covid-19, serta langkah GERMAS diberikan oleh Nofisulastri, M.Si. Pemberian materi dijelaskan diutarakan secara lisan sembari menunjukkan beberapa famplet/gambar ilustrasi terkait Covid-19 yang merujuk panduan Kemkes RI dan ilustrasi sejauh mana progress penyebaran virus secara global ((ditunjukkan Gambar 1 dan 2).

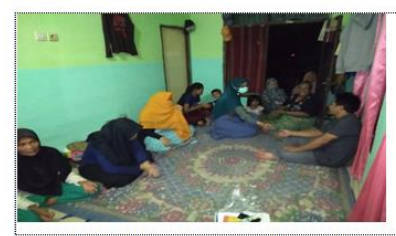

Gambar 1. Pemakaian cairan handsanitizer

Sesi pertama

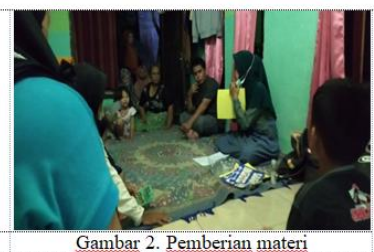

diakhiri dengan pemberian penjelasan singkat terkait cara pencegahan pada level individu dan peningkatan imunitas diri, serta kelompok risiko tinggi terpapar virus Covid-19. Sesi lanjutan, sesi pengenalan GERMAS untuk mencegah penularan Covid-19 berupa gerakan cuci tangan sehat dan senam imun (ditunjukkan Gambar 3, 4, 5). Demonstrasi 6 gerakan cuci tangan sesuai standar WHO dilakukan dengan penggunaan tinta warna untuk menunjukkan simulasi cuci tangan yang benar. Demonstrasi dilakukan sebanyak dua kali dan selanjutnya mengajak peserta melakukan gerakan dengan 3 kali pengulangan gerakan. Setelah dirasakan cukup, selanjutnya dilaksanakan sesi senam terapi imun sederhana yang dipimpin oleh bapak Nurdin, M.Pd yang bergerak dibidang keolahragaan. Gerakan senam tersebut terdiri gerakan sederhana ketuk dada, tepuk tangan, tepuk tengkuk, dan relaksasi pernapasan. Gerakan senam sederhana ini direkomendasikan dan bisa dikerjakan kapanpun dan semua kelompok usia.

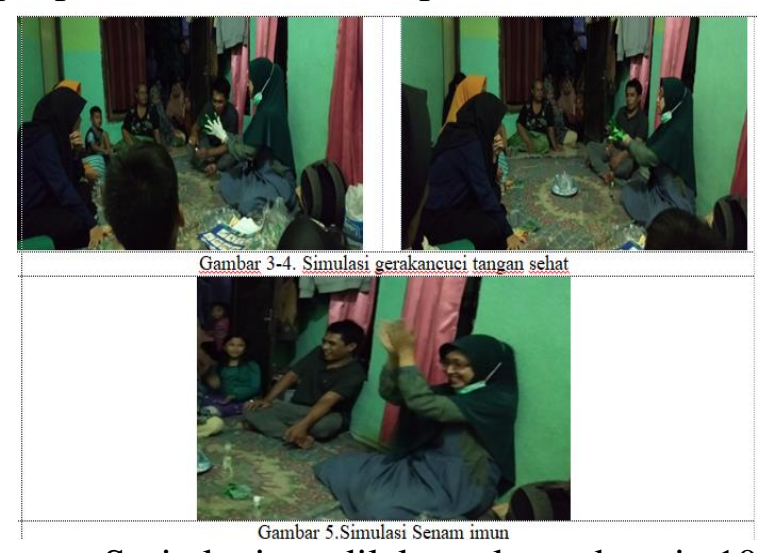

Sesi ketiga dilaksanakan durasi 10 menit berisikan tanya jawab peserta dan quiz berhadiah (ditunjukkan pada Gambar 6 dan 7). Antusiasme peserta terlihat hampir seluruh peserta mengacungkan jari untuk ingin menjawab pertanyaan yang dilontarkan oleh tim pengabdi. Sebanyak 3 (tiga) pertanyaan terkait seputar pengenalan Covid-19 dan gejala klinis oleh peserta yang ditunjuk mampu menjawab dengan benar. Oleh tim pengabdi memberikan hadiah berupa handsanitizer dan gantungan kunci kepada peserta tersebut. Sesi penutupan, oleh seluruh tim bersama peserta melakukan senam gerakan cuci tangan dan senam terapi imun diiringi musik, serta pembagian souvenir berupa masker kain, sabun 
mandi dan handsanitizer ((ditunjukkan Gambar 8 dan 9).

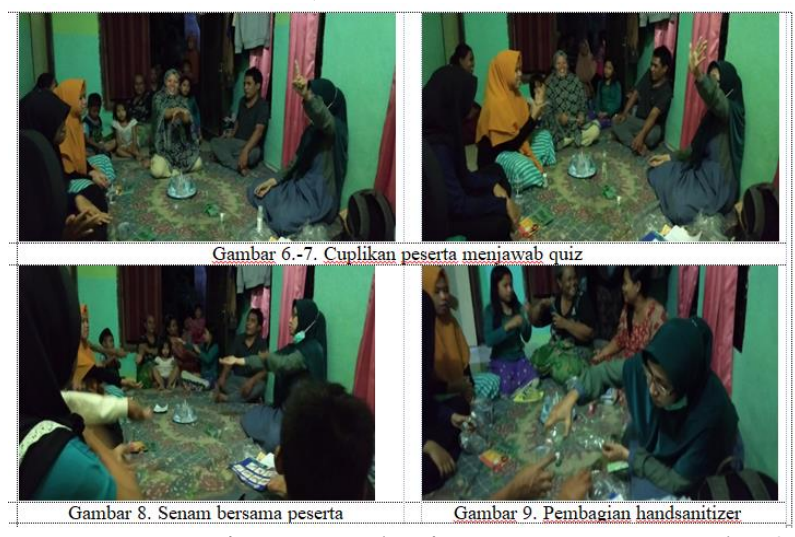

Kegiatan selanjutnya tertanggal 25 April 2020 (09.00-10.00 wita) oleh tim pengabdi dan beberapa peserta ikut melakukan penempelan stiker famplet terkait Covid-19 dan gerakan cuci tangan sehat sebanyak 15 eksemplar dibeberapa titik seperti pos ronda, warung warga, papan pengumuman dusun dan mesjid, dan gerbong pedagang sayur keliling . Gerakan penempelan stiker ini merupakan bentuk sosialisasi tim dengan tujuan informasi ini bisa dibaca dan dipelajari oleh khalayak umum terutama warga dusun Ireng Lauk. Harapan selanjutnya dari keseluruhan kegiatan yang telah dilakukan oleh tim pengabdi bermanfaat dan peserta mampu minimal menerapkan pola hidup sehat dan menstransfer informasi yang telah mereka dapati.

\section{SIMPULAN DAM SARAN}

Kegiatan pengabdian sosialisasi GERMAS Covid-19 bersama Ibu-Ibu warga Dusun Ireng Lauk di Desa Jatisela cukup berjalan lancar. Antusiasme peserta untuk menghadiri kegiatan terlihat dengan jumlah peserta yang hadir melebihi target dan estimasi waktu kegiatan membutuhkan waktu lebih panjang sehubungan warga banyak melontarkan bertanyaan terkait materi.

Kegiatan berupa sosialisasi atau pelatihan GERMAS ini perlu ditindaklanjuti dan menghimbau agar masyarakat tetap tenang menghadapi pandemik wabah virus Covid-19 dengan menerapkan pola hidup sehat dan optimis.

\section{DAFTAR PUSTAKA}

Anugerah M. F., Husnah, Yulianti W., Juariah S., (2019). Penyuluhan Cuci Tangan Pakai Sabun di SDN 128 Pekanbaru Kelurahan Rantau Panjang Pekanbaru. Jurnal Pengabdian Masyarakat Multidisiplin, 3(3), 182-186.

BPS Lombok Barat, (2019). Kecamatan Gunung Sari Dalam Angka: Gunung Sari Subdistrict in Figures. Katalog BPS. Lombok Barat

Fauzie M, Kholisya U., Wijayanto C.S., (2018). Membatik Untuk Anggota Majelis Taklim Salsabila Al Barokah Di Lebak Jakarta Selatan. Jurnal PKM: Pengabdian kepada Masyarakat, 01(2)

Juanita E., Handayani E.Y., Alfiah L.N., (2020). GERMAS (Gerakan Masyarakat Hidup Sehat) di Desa Rambah Hilir. Jurnal Kumawula, 3(1), $100-105$.

Kemkes RI., (2020). Buku Pedoman RT/RW Pencegahan COVID. Diaskes pada tanggal 09 April 2020, web: http//www.promkes.kemkes.go.id 